\title{
Zina, Transnational Feminism, and the Moral Regulation of Pakistani Women
}

\author{
Shahnaz Khan
}

Vancouver, Canada: University of British Columbia Press, 2007. 152 pages.

Using the role of an immigrant researcher in her country of origin, Shahnaz Khan uses her feminist lens to explore dualities, decontextualization, and stereotypes of third-world women, more specifically Muslim women, while examining the contested issue of the Zina Ordinance and its multifaceted consequences for women in Pakistan. Juxtaposing her feminist analysis within the context of transnational feminism, the author examines the tensions surrounding this ordinance by questioning three intersecting contexts, namely, 
culture, politics, and religion. Pointing out such issues as corruption, male violence, poverty, and drug and alcohol abuse, Khan argues that the ordinance allows families, in collaboration with the state, to regulate women's sexuality. She reminds her readers that women charged with adultery and fornication by the state are not victims, as they resist their incarceration in multiple ways. Ironically, the prisons as well as the state-sponsored shelters become safer spaces for women to flee the wrath of their families.

Dissecting her own location as a researcher - both insider and outsider in Pakistan, Khan rightfully points out that her production of knowledge will be consumed by western readers. Navigating an array of postcolonial theoretical frameworks, she correctly questions the role of the researcher's neutrality in knowledge production. As a "third-world academic" in Canada who is expected to pursue a certain kind of research, Khan incisively explores the politics, anxieties, and dilemmas for third-world academics who investigate contested and controversial issues, including sati, male violence, purdah, female genital mutilation, and dowry in their country of origin. According to Khan, these issues are frequently investigated without any contextualization. Westerners, especially the media, often present these issues without linking them to growing poverty, the devaluation of currency, the exorbitant prices of basic necessities, and the influx of arms into Pakistan. Interestingly, her own questions pave a path for moving beyond relativist perspectives that solely focus on cultural, religious, or ahistorical accounts for events.

Contextualizing the ordinance in historical, political, and social processes, rather than focusing on the role of religion (i.e., Islam in Pakistan, a multilingual, multicultural, and multiregional society), Khan challenges stereotypical images of Muslims. To legitimize political regimes in Pakistan, politicians frequently have used Islam, more specifically the Zina Ordinance, as part of the nation-building project. Providing a politico-historical background that nurtures the intersections between Islam and nation-building, the author points out that it was the military dictator General Zia who legitimized his regime through Islamization, which included the Hadood Ordinances (which deal with the prohibition of drug and alcohol consumption) as well as the Zina Ordinance, a strategy to control women's sexuality and socio-economic-politico mobility. Ironically, according to her, Pakistan under the General Zia was one of the top four recipients of American aid. In addition, the United States both supported the Afghan rebels who lived and organized in Pakistan and strengthened the Islamization process.

Methodologically, Khan's analysis of the ordinance's effects on women in Pakistan is based on her fieldwork conducted in that country from 19982002. Visiting prisons in Lahore and Karachi, as well as having conversations 
with officials and women in prison while an official was present, provided her with the ammunition for her analytical tools. The absence of women's voices is noteworthy; however, Khan clearly describes the constraints of interviewing women in prison. To rectify this major methodological limitation, she supervised two research assistants who for six months ran a women's group in a prison where the majority of inmates were there on zinarelated charges. Through this unconventional feminist research process, Khan was able to gain insights into their lives both in and out of prison. Interestingly, these women sang both Indian and Pakistani film songs, as well as devotional songs, that evoked love and romance, which ultimately helped them survive their incarceration.

Ironically, their own love and romance, their personal choices of a lover, were identified as "crimes." Family members, in collaboration with the state, identified these women as "disobedient daughters and errant wives." For this, they were found guilty and imprisoned. A weak rehabilitation program has made it harder for them to reenter society. According to Khan, the ordinance has facilitated the portrayal of middle-class women as docile and of workingclass women as sexually promiscuous. In other words, this state-orchestrated ordinance strengthens male/family members' power to control daughters, wives, and mothers in multifaceted ways, including verbal threats.

Reviewing women's progress in Pakistan since its independence in 1947, Khan unwittingly credits "professional” women's resistance against the ordinance. This kind of credit creates an elite feminism in her analysis. However, the Hadood Ordinances, including the Zina Ordinance, were passed in 1979 amidst protest. The Women's Action Forum, which is mostly urban-based, formed during this period, and several women's groups and NGOs in towns and villages developed. Khan's underestimation of the role of the middle and working classes in the women's movement in Pakistan is problematic.

Although she demonstrates the ordinance's effects upon women, Khan calls for a transnational feminist movement that is uneven in substance, significance, and style. The book restates some relatively well-known material, although several of the six chapters provide insightful, valuable discussions of women's lives in Pakistani prisons. The dominant theme in the discussion is class without explanation - Khan unquestioningly uses concepts like "lower class" and "impoverished."

Given Pakistan's current political situation, the book will likely be of most interest to those with a fairly high level of expertise in the field. For academics, it can be a valuable text for specific courses like "Women in Society," 
"Women in Islam," and "Politics in South Asia/the Third World." Despite its limitations, the book can also serve as a useful reference for many women's studies courses.

Habiba Zaman Associate Professor, Department of Women's Studies Simon Fraser University, British Columbia, Canada 